\title{
Irrigation Post-Modernization. Farmers Envisioning Irrigation Policy in the Region of Valencia (Spain)
}

\author{
Carles Sanchis-Ibor ${ }^{1, *(\mathbb{C})}$, Mar Ortega-Reig ${ }^{1,2}{ }^{,}$Amanda Guillem-García ${ }^{1}$, Juan M. Carricondo ${ }^{1}$, \\ Juan Manzano-Juárez ${ }^{1}$, Marta García-Mollá ${ }^{1}$ and Álvaro Royuela ${ }^{1}$ \\ 1 Centro Valenciano de Estudios del Riego, Universitat Politècnica de València, 46022 València, Spain; \\ marvioleta@gmail.com (M.O.-R.); amguigar@upvnet.upv.es (A.G.-G.); juacaran@upv.es (J.M.C.); \\ juamanju@agf.upv.es (J.M.-J.); mgarmo@esp.upv.es (M.G.-M.); aroyuela@agf.upv.es (Á.R.) \\ 2 Institut de Desenvolupament Local, Universitat de València, 46010 València, Spain \\ * Correspondence: csanchis@hma.upv.es; Tel.: +34-963-877-475
}

Citation: Sanchis-Ibor, C.; Ortega-Reig, M.; Guillem-García, A.; Carricondo, J.M.; Manzano-Juárez, J.; García-Mollá, M.; Royuela, Á. Irrigation Post-Modernization. Farmers Envisioning Irrigation Policy in the Region of Valencia (Spain). Agriculture 2021, 11, 317. https:// doi.org/10.3390/agriculture11040317

Academic Editors: Ivan

Francisco Garcia Tejero and Victor Hugo Durán-Zuazo

Received: 28 February 2021

Accepted: 31 March 2021

Published: 4 April 2021

Publisher's Note: MDPI stays neutral with regard to jurisdictional claims in published maps and institutional affiliations.

Copyright: (c) 2021 by the authors. Licensee MDPI, Basel, Switzerland. This article is an open access article distributed under the terms and conditions of the Creative Commons Attribution (CC BY) license (https:// creativecommons.org/licenses/by/ $4.0 /)$.

\begin{abstract}
During the last three decades, like many other Mediterranean states, Spain has intensively promoted the modernization of irrigation, focusing mainly on the introduction of pressurized irrigation systems. Following 30 years of investment, a shift in irrigation policies is needed to solve some of the deficiencies in this modernization process and to incorporate new measures to cope with upcoming challenges generated by international markets, climate change and other social and economic processes. This paper describes and analyses the results of participatory research carried out with the water user associations in the autonomous region of Valencia, in order to define post-modernization irrigation policies. A survey and 24 local workshops involving 304 water user associations were conducted during the irrigation season of 2018 in order to form an assessment of the sector and design new irrigation policies. The results show that after 30 years of important investment, the obsolescence of the infrastructure has become the current main priority, making farmers dependent on public subsidies. New necessities have also emerged, such as renewable energies and nonconventional water resources, which farmers consider indispensable in order to reduce operating costs and guarantee water supply.
\end{abstract}

Keywords: irrigation modernization; irrigation policy; drip irrigation; integrated water resources management; infrastructure obsolescence

\section{Introduction}

The twentieth century was the century of the expansion of irrigation. The world's irrigated areas increased from 63 million ha (Mha) in 1900 to 306 Mha in 2005 [1], stimulated by the consideration of water as a key economic asset, population growth, technological changes and the mass mobilization of water resources. However, at the end of the last century, increasing pressure on water resources motivated the revision of this hydraulic paradigm and a shift towards the pursuit of irrigation efficiency. This process, frequently termed modernization, has been driven by farmers, companies, governmental agencies, and supported by international organizations [2-4] in various regions of the world. It has generally involved the adoption of various pressurized irrigation techniques. Today, $25 \%$ of the world's irrigated areas use these techniques, $60 \%$ in developed countries [5], while an undetermined area has opted for concrete-lined channels and other efficiencyoriented techniques.

In Mediterranean countries, national and regional governments have supported these irrigation modernization programmes, with subsidies covering between 40 and 100\% of investment in different countries [6,7]. The participation of farmers' associations in these modernization processes has reached different levels, conditioned by the unequal robustness of collective management institutions in each country [7]. As a result of these 
processes, pressurized irrigation has rapidly expanded, reaching approximately 10.7 Mha in the last decade $-48 \%$ of Mediterranean irrigated land [8].

The rapid technological shift has provoked numerous changes in irrigation practices and institutions [9-13], water management and water resource savings [14-19], and energy costs [20-22]. Some of these changes were more or less explicitly defined as objectives of the modernization mission, but many others are unforeseen effects caused by the lack of an ex ante integrated analysis of both irrigation management and technological change processes [23-25].

The extensive scientific research in this field proves that, after three decades of investment and transformation, irrigation policies need to correct the unexpected negative effects of these modernization processes (rebound effect on water consumption, increased energy costs or loss of social control $[13,16,20,22])$, while at the same time new measures are required to cope with upcoming challenges generated by international markets, climate change and other social and economic processes. Researchers have paid major attention to the development of new techniques to improve the efficacy and efficiency of irrigation, and a rallying call for a second generation of modernization, mainly based on remote sensing and information and communication technologies (ICTs), can be inferred from numerous recent studies and institutional recommendations [26-28]. These works are mainly oriented towards the most dynamic and innovative irrigation clusters and water user associations (WUAs), and rarely to smallholding agriculture or traditional irrigation.

Literature focusing on the regional scale, which would enable a wider typological scope of irrigation systems to be considered, is scarce, and these approaches rarely pay attention to the farmers' perceptions, which play a key role in irrigation modernization processes. For these reasons, this paper focuses on the autonomous region of Valencia (Spain) to analyze the results of participatory research [29] carried out with the majority of the WUAs in the region, with the goal of redefining irrigation policies for the next 20 years. This Mediterranean region has made a significant financial and technical commitment to stimulate irrigation modernization during the last three decades, as have many other regions in Spain [30]. Therefore, it represents an interesting case study to observe how farmers tackle the effects of the past modernization processes and how they envision post-modernization irrigation policies. It is a worthwhile experience for others of the numerous semiarid countries that have undergone or are developing similar policies of modernization of irrigation systems [6,7,31].

The paper has four main objectives. First, to identify farmers' and WUAs' problems after a process of irrigation modernization lasting three decades; second, to identify farmers' and WUAs' priority measures to overcome their current challenges; third, to identify the consequences of the irrigation policies focused on the subsidized adoption of pressurized irrigation techniques; and finally, to reflect on the changes that have taken place in the irrigation modernization paradigm in the last three decades.

The paper is structured as follows: first, the methodological aspects are described; second, the quantitative results of the assessment and measure design tasks carried out by the WUAs are presented; subsequently, in the discussion section, the data is analyzed using the notes taken during the workshops and relevant literature; and finally, some brief conclusions are drawn.

\section{Materials and Methods}

The study area encompasses the irrigated lands of the autonomous region of Valencia, on the eastern Mediterranean coast of Spain. The region is host to a varied array of irrigation landscapes: small traditional terrace systems in mountain areas; rice paddy areas in wetlands; large canals built by the state during the twentieth century; groundwater areas for vineyards, fruit and olive production; and a vast citriculture area $(180,000 \mathrm{ha})$ provided both with groundwater and surface water from historical channels. In total, there is an area of 336,000 ha of irrigated land [32], of which $32 \%$ is supplied with groundwater, $60 \%$ with surface water and $7 \%$ with nonconventional resources. Most of the irrigated 
lands (72\%) use pressurized systems, and $28 \%$ retain gravity irrigation [33]. Smallholdings predominate markedly. The mean size of farms is 5.5 ha and the mean size of irrigation plots is 0.52 ha [34]. Part-time farming accounts for over $40 \%$ of the area [35], while a dramatic ageing process threatens the generational renewal of farming activity (the mean age of farmers is 64.5) [36]. The vast majority of the irrigation systems are collectively managed through WUAs. Both the regional and national governments have provided subsidies for WUAs to modernize their irrigation systems since the 1980s, particularly after 1995, through their departments for agriculture and water management. These subsidies covered $40-50 \%$ of costs for local investments and $100 \%$ in the case of general-interest investments. The Basin Authorities (Confederaciones hidrográficas), belonging to the Ministry of the Environment, are the institutions authorized to control water rights, water allocation and water quality, and for the fulfilment of the European Water Framework Directive.

The first step in the participatory research was a survey sent in May 2018 to all the WUAs in the region by email and post, which was answered by 214 WUAs, representing approximately $68 \%$ of the irrigated land. This survey collected detailed information on the structure, water resources, crops, infrastructures and costs from each WUA, and also asked for an assessment describing the main problems faced by farmers, and the solutions required or proposed by the WUAs to guarantee the viability of their agricultural activity.

With this information, and based on bibliographic sources, the region was divided into 24 clusters according to agronomic, water resource and geographical criteria (Figure 1). Most of the resulting clusters coincided with well-known geographical units or historical districts (comarcas in Spanish). Some of them had supra-WUA institutions for the collective defense of their common interests, which were contacted to organize and stimulate WUA participation. The geographical criterion was not strictly adhered to. In three cases these districts or geographic units were subdivided into two or three different clusters due to the existence of irrigation systems with very different hydraulic characteristics and traditions, while in two other cases several geographic units were merged due to the similarity of their irrigation systems and the small size and number of the irrigated areas.

In each one of these districts, a local workshop was organized, to which all the WUAs in the area were invited by email or telephone, directly or with the support of key local agents such as members of the city councils or representatives of agrarian trade unions, cooperatives or large WUAs. In total, 304 WUAs attended these meetings, representing approximately half of the regional WUAs, but almost $80 \%$ of the irrigated lands in the region. The meetings took place between June and November 2018. In general terms, attendance to meetings was proportional to the size of the irrigated lands and number of WUAs in each cluster. In three other cases, four WUAs that had been summoned to a meeting were unable to attend it, or attended another, their votes being counted separately and added to those of their cluster.

The workshops, with an approximate duration of between two and three hours, were structured into three parts. In the first part, after a brief presentation of the goals and tasks of the meeting, the moderator presented a preliminary assessment of the situation of the irrigation sector in the district, based on the results of the survey. Afterwards, the moderator opened a discussion among the representatives of the WUAs to complete or correct the list of problems and challenges detected in the area, asking for the substantiation of each fact or for additional contextual information where necessary. The issues were recorded verbatim in the way the farmers freely expressed and defined them.

The second part repeated the dynamic of the first, but in this case the discussion focused on the strategies, solutions and measures to be taken by both the WUAs and the public administration (regional and national departments and agencies) to cope with the challenges identified during the first part. The third part was dedicated to prioritization. Farmers were required to grade all the items of the lists of problems and measures identified during the workshop according to a four-point scale for problems (irrelevant; low importance; important; and very important) and measures (undesirable; low importance; necessary; and critical). Only one vote per WUA was allowed, regardless of the number of 
representatives from each WUA attending the meeting. Prioritization was anonymous, but WUAs had to use different colored stickers for voting according to the principal origin of their water resources.

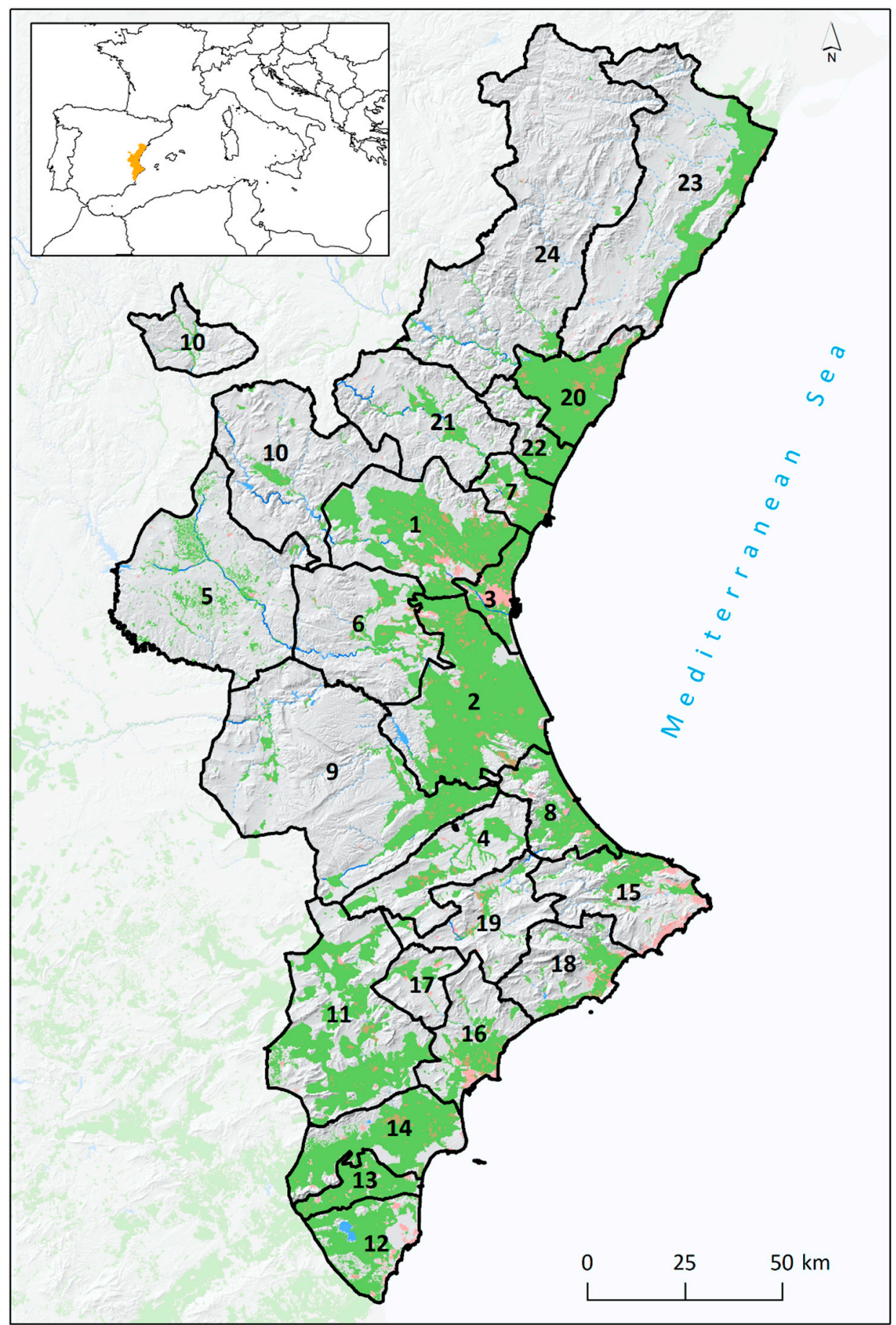

Figure 1. Workshops took place in these 24 clusters, defined according to agronomic, water resource and geographical criteria. Green coloured areas represent the irrigable areas in the region. 1. Camp de Túria, 2. Ribera del Xúquer, 3. L’Horta de València, 4. Vall d'Albaida, 5. Requena-Utiel, 6. Buñol-Chiva, 7. Camp de Morvedre, 8. La Safor, 9. Caroig-Cànyoles, 10. Alto Turia, 11. Vinalopó, 12. La Pedrera, 13. Vega Baja, 14. Riegos de Levante, 15. Marina Alta, 16. Alacantí, 17. Foia de Castalla, 18. Matina Baixa, 19. Alcoià-Comtat, 20. Plana de Castelló, 21. Alto Palancia, 22. Plana Baixa, 23. Baix Maestrat, 24. Ports-Maestrat-Alt Millars. 
After the voting, the workshop was formally closed, although in most cases discussions with farmers and regional government continued in different groups, which also provided valuable information that some farmers did not want to share in public. A few days after each meeting, the minutes written out by the research team were sent to all the participants to give them the opportunity to review the results and conclusions of the workshop and provide them with the opportunity to make corrections or provide any additional information. The WUAs only corrected or clarified the opinions recorded in the minutes in three of the 24 meetings. In two cases, the WUAs that could not attend the meeting asked for the minutes and sent back an addendum including their views, needs and proposals. Finally, the research team processed the results of the prioritization.

The information obtained from the workshops was reorganized and categorized. The farmers raised 468 problems and 409 measures; however, many of them voiced identical information using synonymous language or with different local nuances, so after the meetings the results were standardized in the database into categories of 75 problem-types and 83 measure-types. For instance, the measure-type "Improving tanks" corresponds to four proposals from different meetings, in which it was expressed as "Improving tanks", "Improving existing tanks", "Improving tank" or "Improving and renovating tanks". Once the typology and classification had concluded, the results were screened to avoid duplication in vote counting, as shown in Figures 2-9.

Each meeting took place in an irrigation district with specific characteristics. Using information from the survey conducted in May 2018 and statistical data [31,37,38], the 24 meeting areas were classified according to different water management or agronomic variables, such as crop pattern, irrigation technique, water resource origin and water resource availability. This allowed us to analyze whether farmers' responses were somehow conditioned by the characteristics of these three variables:

- According to the official water planning instruments of the river basin authorities [37,38], which estimate the water balance of all the water bodies in the region, four levels of water resource availability were identified: first, areas with sufficient (positive water balance) surface and groundwater resources; second, areas with insufficient groundwater or surface water resources; third, areas with insufficient water resources but receiving external resources from interbasin water transfers (Tajo-Segura or JúcarVinalopó); and finally, areas with both insufficient surface and groundwater resources.

- Regarding the irrigation techniques used in these areas, using the information of our survey, four categories were identified: drip (> 75\%); surface (> 75\%); mixed, with drip predominance (50-75\%); and mixed, with surface predominance (50-75\%).

- Water resource origin was established using the information collected in our survey and in the Segura and Jucar Basin Authorities current (2015-2021) Water Plans [37,38] and the different colored stickers used by farmers during the voting according to the origin of the water resources. These were classified into three groups: groundwater users, surface users, and mixed groundwater-surface users.

\section{Results}

\subsection{Deficiencies and Challenges of the Irrigation Sector after Modernization}

The main problem of the irrigation sector in the region, according to the WUA representatives, is the obsolescence of drip irrigation infrastructures, which was considered as critical or important by $81 \%$ of the meeting attendees (Figure 2). Two further problems, land abandonment caused by low profitability and lack of generational renewal and water resource scarcity, also achieved a notable valuation (69 and 75\%, respectively). The cost of energy for irrigation was also highlighted in fourth position (67\%), but was the most highly voted issue as a critical problem (54\%). Although objectively the WUA representatives assessed these facts in a similar way, in most of the meetings their discourse focused on the crisis of the agricultural system, defining farmers as an "endangered species" (Workshop 3, Figure 1), and lamenting the lack of new "blood", because "young people never pick up the hoe, only the mobile phone" (Workshop 4, Figure 1). In some of the meetings, some local 
leaders brought a prepared speech (in some cases written) formulating their arguments. The majority of the other problems detected were considered as factors that intensified this situation of low profitability, mainly because they were inputs of the production chain or they indirectly affected the structure of costs of the agricultural landholding. The relative importance of these factors had different territorial variations throughout the region.

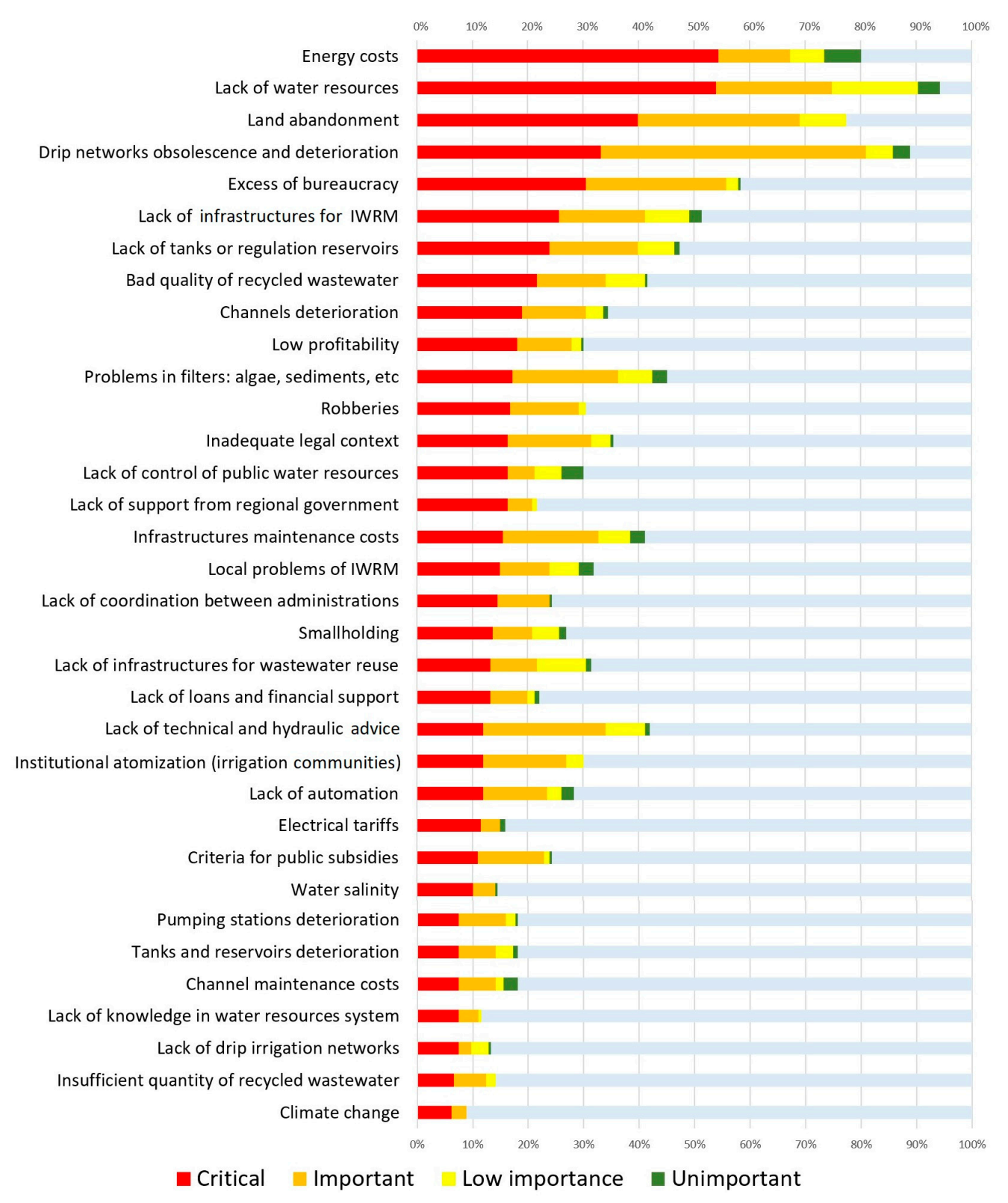

Figure 2. Assessment of the irrigation sector problems: results of the attendee assessment in terms of percentage of total votes.

After these four major causes of concern-some way behind-the WUAs gave secondary importance to other factors concerning institutions, water resources, operation and maintenance tasks (O\&M) and social problems. In the institutional arena, the regional department of agriculture and the water basin authorities were the target of numerous complaints, with the farmers' assessments stating that they played a key part in the crisis of the irrigation sector. In some workshops, farmers angrily expressed feelings of being abandoned by the regional and national governments. In this sense, farmers denounced an excess of bureaucracy $(56 \%)$, loopholes or inappropriate provisions in the legal framework for water management (32\%), lack of control or rule enforcement by water basin author- 
ities $(21 \%)$, lack of support from the regional government (21\%), or lack of coordination between different departments and authorities in the regional and national governments $(24 \%)$. There was also a significant concern regarding the excessive atomization of the institutions for collective management of irrigation; a particularly worrying aspect in some groundwater-irrigated areas was that numerous small organizations had been created during the twentieth century to tap the aquifers (27\%).

Apart from the regional structural scarcity of water, WUAs identified 13 problem-types related to water resources, some of which received a significant number of votes. Numerous WUAs had a clear idea of the deficiencies in their water resource system, and had made a prior assessment of the infrastructure needed for better-integrated management, or that required the mobilization of more water resources. For this reason, the lack of integration of local water resource management (41\%) and specific problems of local water management $(23 \%)$ were also highlighted. Farmers explained that the lack of storage facilities such as tanks or small reservoirs $(40 \%)$ needed to be redressed to improve water management within irrigation communities, but problems of integrated water management at local level, and more specifically the possibility of using recycled wastewater, were also associated. Perceived as a valuable alternative to exhausted traditional water resources, recycled wastewater was frequently mentioned by the attendees, particularly regarding lack of quality (34\%), quantity (13\%), and lack of infrastructure for distribution $(22 \%)$.

Various problem-types related to maintenance tasks and costs appeared among the 25 most voted problem-types. Those related to drip irrigation expansion, algae and sediments in filters (36\%), and theft of metal components (29\%) seemed to be slightly more significant than those related to traditional irrigation (channel deterioration $31 \%$ and maintenance $15 \%$ ). It is also significant to highlight the lack of hydraulic and technical advice, which was rated as important or very important by $34 \%$ of attendees. Finally, farmers placed other problems on a third level (below 10\%), some of them being more specific (for instance, lack of other technical advice, legislation obstacles, etc.) and others more generic, such as gender inequality $(6 \%)$ or climate change $(9 \%)$, which were far from being their main concerns.

This order of priorities significantly changes when the WUAs responses are classified according to different criteria. Considering water resource availability (Figure 3), in those districts with sufficient water resources, land abandonment was clearly indicated as the main problem $(83 \%)$, while drip irrigation and gravity irrigation infrastructure obsolescence (51 and 53\%, respectively) were also highlighted. Lack of water was valued by $33 \%$ WUAs as important or very important. In areas with partial or total insufficiency of water resources (Figure 3b,d), lack of water resources ranked in second (53\%) and eighth (42\%) place, respectively, with energy consumption costs regarded as the main problem $(64 \%$ in both areas). Obsolescence was the second biggest problem, sharing this position with land abandonment in areas with moderate abundance. In areas with insufficient local resources and receiving external transfers (Figure 3c), lack of water was a less significant problem, and only $22 \%$ of WUAs identified it as critical. In these areas, nine problems ranked higher, mainly lack of infrastructure for integrated water resources management (IWRM) (63\%), lack of quality of recycled wastewater $(60 \%)$, irrigation network obsolescence $(47 \%)$ and lack of small reservoirs for irrigation regulation (44\%). 
a

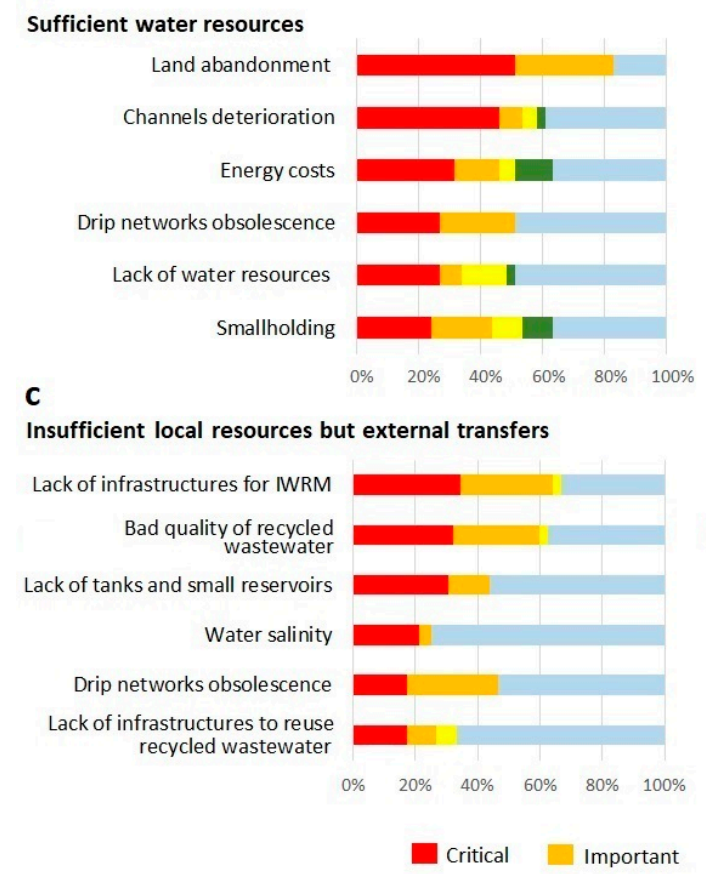

b

Insufficient groundwater or surface resources

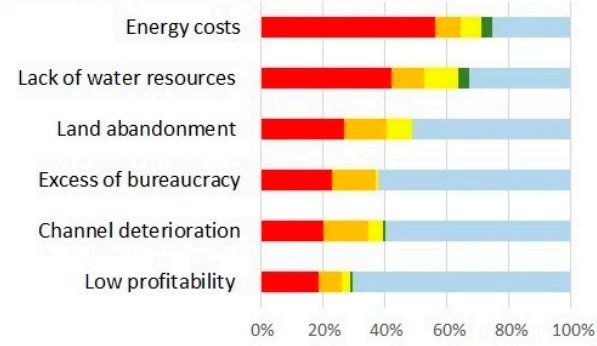

d

Insufficient groundwater and surface resources

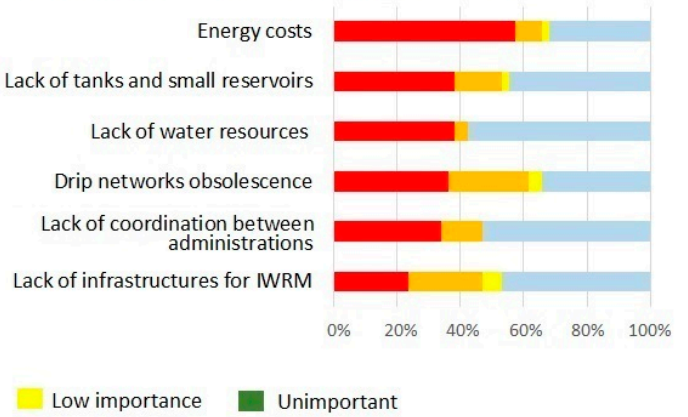

Figure 3. Problem assessment according to water resource availability: evaluated in terms of percentage of total votes. (a) Sufficient water resources; (b) Insufficient groundwater or surface resources; (c) Insufficient local resources but external transfers; (d) Insufficient groundwater and surface resources.

The reclassification of the assessment according to irrigation techniques provides different results in traditional gravity irrigation and drip irrigation areas. Land abandonment ranked first $(69 \%)$ in those districts that predominantly $(>75 \%)$ use gravity systems, and second in areas mostly (50-75\%) employing traditional gravity distribution networks (Figure $4 \mathrm{a}, \mathrm{b})$. However, in districts where drip irrigation is clearly predominant $(>75 \%)$ or slightly predominant (50-75\%), both energy costs (59 and 64\%) and network obsolescence (63 and 64\%) arose as the most significant problems (Figure 4c,d). Lack of water ranked among the five most significant problems in all cases; nevertheless, it is important to stress that in gravity irrigation areas it was placed below the lack of water control (extraction and spillage) on the part of the basin authority. Theft and vandalism, the lack of regulation reservoirs, the lack of technical advice or support, and bureaucratic excess were emphasized in drip irrigation areas, while low profitability, lack of political support or lack of automation systems were given higher preference in drip areas (Figure 4).

Following the criteria based on the origin of water resources, very similar results were obtained (Figure 5). The areas using surface water (where gravity irrigation also predominates) presented a greater concern for channel maintenance (54\%) and land abandonment $(43 \%)$, and also some worries regarding water shortages and network obsolescence (both $35 \%)$. On the other hand, in groundwater and mixed areas, concerns concentrated on energy costs (66 and 63\%, respectively), network obsolescence (58 and 63\%), lack of tanks and local regulation reservoirs (44 and $41 \%$ ) and water shortages ( 43 and $58 \%$ ). Mixed areas presented a significantly higher concern for land abandonment (53\%) than in groundwater areas $(33 \%)$. 
a

Gravity irrigation

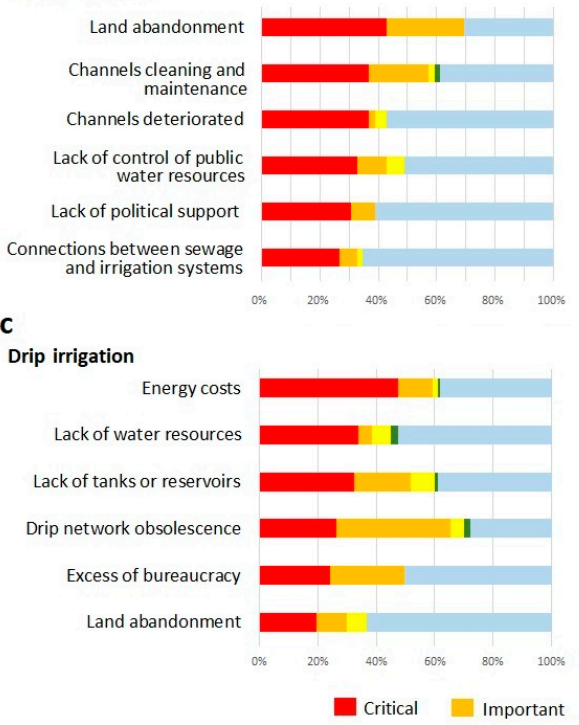

b

Predominantly gravity irrigation

Lack of water resources

Land abandonment

Low profitability

Lack of automation

Lack of knowledge on

water resources

Bad quality of treated

wastewater

Predominantly drip irrigation

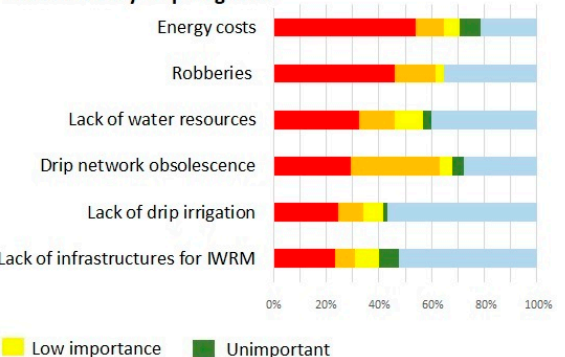

Figure 4. Problem assessment according to irrigation technique: evaluated in terms of percentage of total votes. (a) Gravity irrigation; (b) Predominantly gravity irrigation; (c) Drip irrigation; (d) Predominantly drip irrigation.

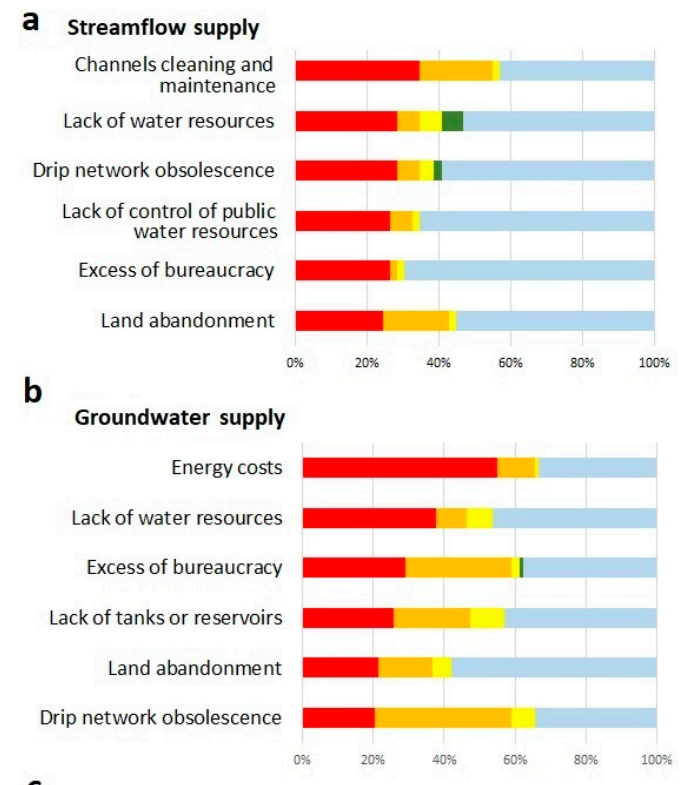

Streamflow and groundwater supply

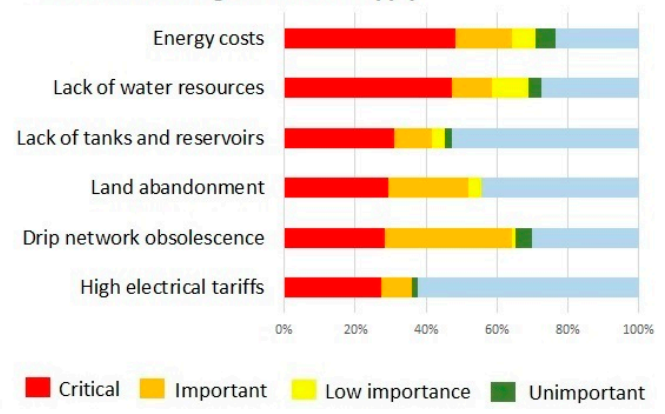

Figure 5. Problem assessment according to different water supply sources: evaluated in terms of percentage of total votes. (a) Streamflow supply; (b) Groundwater supply; (c) Mixed streamflow and groundwater supply. 


\subsection{Proposal and Prioritization of Measures}

At the regional level, to improve the situation of the irrigation sector, farmers expressed a significant preference for one measure: the development of public plans for the renewal of drip irrigation networks ( $66 \%$ of votes regarding it as important or very important). In some meetings, farmers underscored the necessity of retaining public subsidies $(18 \%)$ and some called for these subsidies to be conditional upon the compliance of some specific objective or indicator $(18 \%)$. Some way below these concerns, farmers appealed for the construction of new tanks and small regulation reservoirs (49\%). The construction of new storage facilities of up to $2 \mathrm{Mm}^{3}$ capacity, was aimed at regulating irrigation at the local or district level, and, in some cases, it was also planned to facilitate wastewater reuse or conjunctive use projects. The improvement of existing tanks was also mentioned by $17 \%$ of voters (Figure 6).

After these infrastructural measures, farmers called for a further two related measures: infrastructure and management measures to improve IWRM at the district or local level (42 and $45 \%$, respectively). Infrastructure measures to improve IWRM included a wide array of engineering solutions that varied locally, including pipelines and pumping stations to enable wastewater reuse or desalinated water distribution, weirs to divert water from some nonregulated small rivers, and well interconnection systems to improve conjunctive use, among others. Some of these measures are projects that have been designed during the last 30 years and are well known at the local level, but have never been executed. Management measures to improve IWRM included actions such as developing drought plans and integrated management plans, incorporating available recycled wastewater resources, and either employing or maximizing the use of some existing conveyance infrastructures.

After these four priorities, the WUAs called for more training and technical advice, primarily addressing farmers (39\%), but also technicians working in irrigation communities (23\%). Aspects to be covered by this support were also specified during the meetings, highlighting hydraulic advice for drip irrigation management $(22 \%)$, training for legal and administrative tasks to improve communication with the regional department of agriculture and the basin authorities (18\%), and for photovoltaic technologies and quality control. Farmers also asked for the basin authority to maintain stricter control over public water resources $(16 \%)$.

The sixth measure, the installation of photovoltaic systems (33\%), is not only linked to hopes of curbing energy costs as much as possible but also to some comments on the difficulties of obtaining areas in which to locate this infrastructure. This led some farmers to call for other types of renewable energies as an alternative $(21 \%)$. Along with these demands, WUAs ranked in ninth position the installation of new drip irrigation systems $(40 \%)$.

More than one in four attendees (26\%) prioritized the improvement of wastewater quality, mainly to reduce the salinity of the effluent, as a key strategy to boost the reuse of the current resources in order to overcome the structural water scarcity. A further $23 \%$ highlighted the need for automation devices for drip or gravity networks. Finally, it is important to note that the seventh place in the ranking was for an institutional measure, expressing the necessity to create collective institutions to coordinate or integrate the existing WUAs (28\%); this being particularly relevant in some groundwater areas with an overly atomized institutional structure and governance problems. 


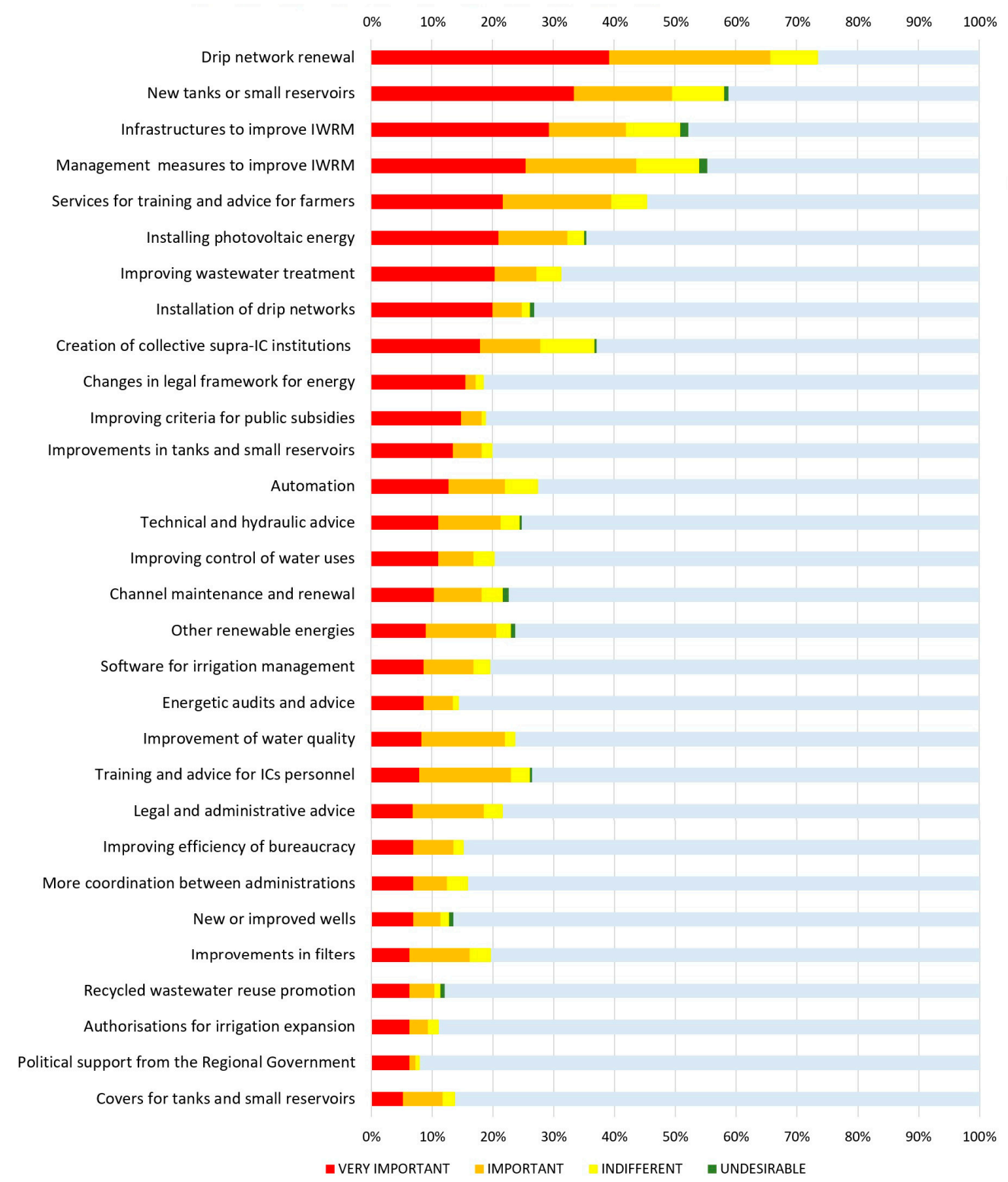

Figure 6. Measure evaluation: results of the attendee assessment evaluated in terms of percentage of total votes.

As with the assessment, the prioritization of measures showed different patterns according to the availability (Figure 7) and origin of water resources, and the irrigation techniques (Figure 8). Regarding water security, in those areas with a certain abundance of water resources (Figure 7a), the focus was mainly on channel network maintenance (80\%), and secondly on the installation of photovoltaic power stations (55\%). WUA representatives also demanded greater efficacy on the part of the regional department of agriculture when it comes to project development (53\%), small reservoirs for irrigation regulation (47\%), and the expansion of the irrigated area over traditional rain-fed areas through supplemental irrigation $(44 \%)$ to increase production and resilience to droughts. Network maintenance was also the most voted measure in areas with partial $(78 \%)$ or total $(83 \%)$ local water resource insufficiency, followed by the construction of new tanks and reservoirs $(67 \%)$ and drip irrigation installation (52\%) in the former case, and installing photovoltaic energy (64\%) and building irrigation reservoirs (59\%) in the latter. In areas depending on external supply sources (Figure 7d), the most valued measure was that of improving treated wastewater quality $(65 \%)$ in order to facilitate agricultural reutilization (reducing the impacts of salinity). It was followed by the demand for new pipelines in order to interconnect this area with 
small neighboring basins with temporary water resource surplus (57\%), or management measures for IWRM (55\%), such as maximizing the use of coastal desalination plants.

a

Sufficient water resources

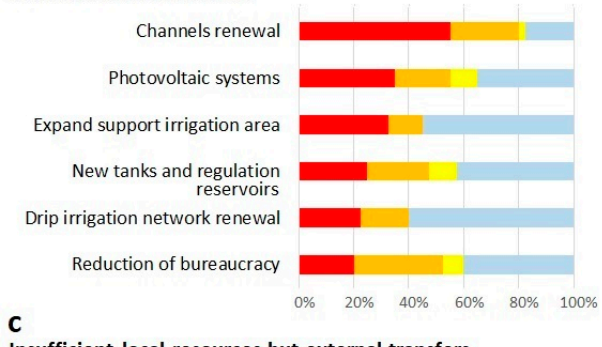

Insufficient local resources but external transfers

Improvement of wastewater
treatment

Mangement measures to

Improving tanks and regulation

reservoirs
Water transfers from

New tanks and regulation
reservoirs

Infrastructures to

$0 \% \quad 20 \% \quad 40 \% \quad 60 \% \quad 80 \% \quad 100 \%$

- VERY IMPORTANT IMPORTANT b

Insufficient groundwater or surface resources

Drip irrigation network renewal

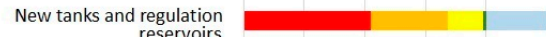

Installation of drip irrigatio

Changes in electrical tariffs

Automation

Infrastructures to

improve IWRM

d

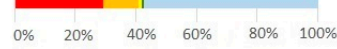

Insufficient groundwater and surface resources

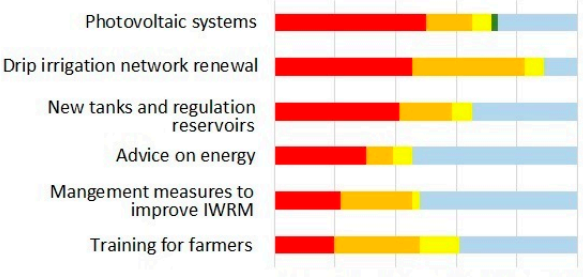

$\begin{array}{llllll}0 \% & 20 \% & 40 \% & 60 \% & 80 \% & 100 \%\end{array}$

- INDIFFERENT = UNDESIRABLE

Figure 7. Measure evaluation according to water resource availability: evaluated in terms of percentage of total votes. (a) Sufficient water resources; (b) Insufficient groundwater or surface resources; (c) Insufficient local resources but external transfers; (d) Insufficient groundwater and surface resources.

a

Gravity irrigation

Channel network renewal

Improving wastewater treatment

New tanks and reservoirs

Installation of drip irrigation

Management measures to improve IWRM

Improving control of water

uses

C

\section{Drip irrigation}

Drip networks renewal

Installation of photovoltaic systems

New tanks and reservoirs Improving treate wastewater

Improvement of tanks and reservoirs

Energy advice and audit
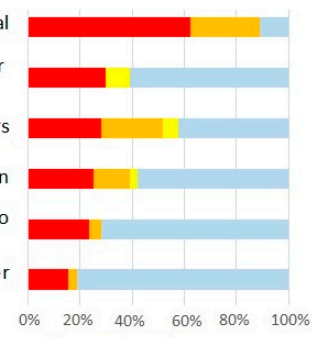

$\begin{array}{llllll}0 \% & 20 \% & 40 \% & 60 \% & 80 \% & 100 \%\end{array}$

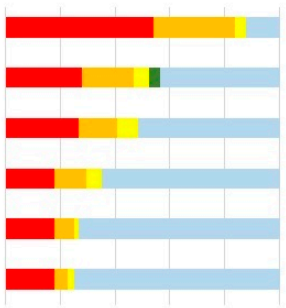

$\begin{array}{llllll}0 \% & 20 \% & 40 \% & 60 \% & 80 \% & 100 \%\end{array}$

- VERY IMPORTANT $=$ IMPORTANT b

Predominantly gravity irrigation

Improving wastewater treatment

Subsidies

New tanks and reservoirs

Infrastructures for IWRM

Drip network renewal

Reservoirs to retain storm rainfall

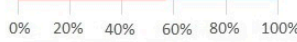

d

Predominantly drip irrigation

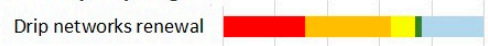

Automation

New tanks and reservoirs

Installation of drip irrigation

Software for irrigation

management

Changes in the legal

framework for energy

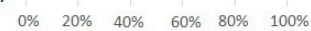

INDIFFERENT I UNDESIRABLE

Figure 8. Measure evaluation according to irrigation technique: evaluated in terms of percentage of total votes. (a) Gravity irrigation; (b) Predominantly gravity irrigation; (c) Drip irrigation; (d) Predominantly drip irrigation. 


\section{a Streamflow supply}

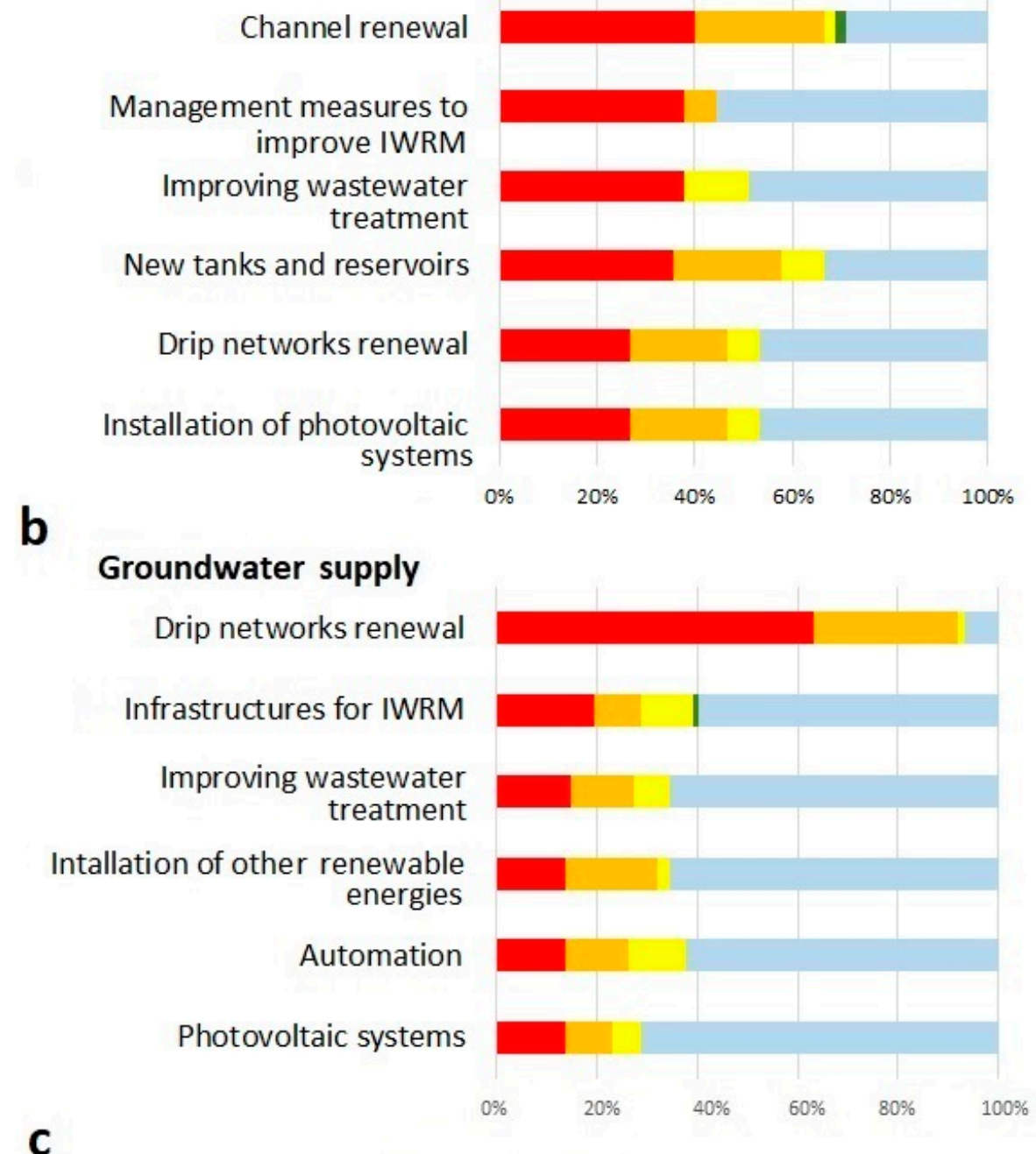

\section{Streamflow and groundwater supply}

New tanks and reservoirs

Channel renewal

Photovoltaic systems
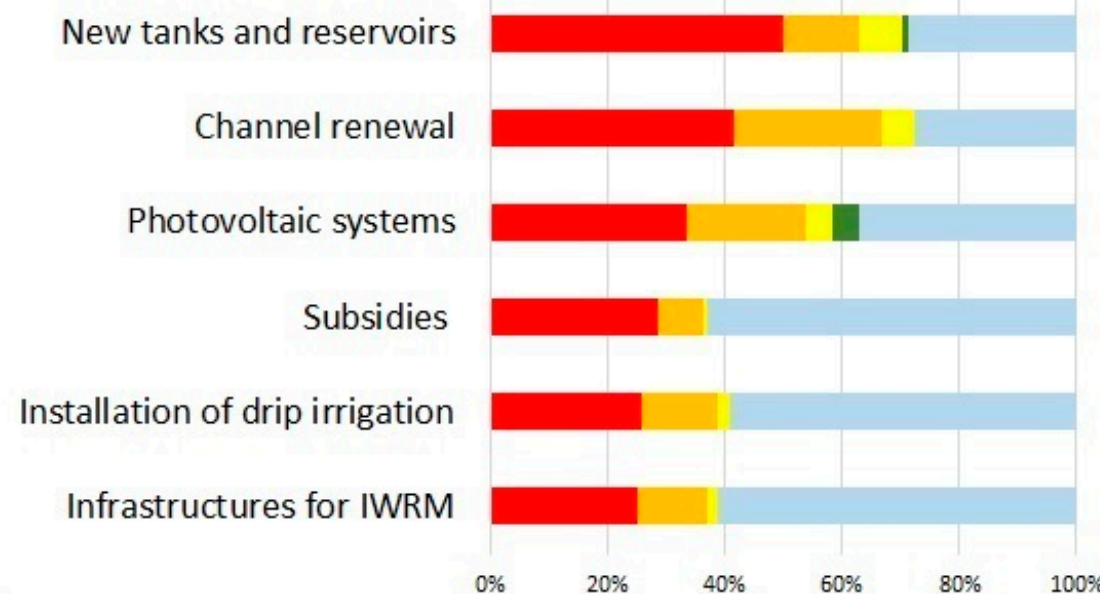

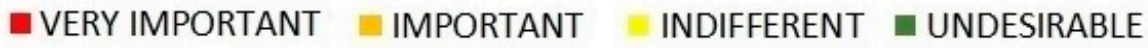

Figure 9. Measure evaluation according to the origin of water resources: evaluated in terms of percentage of total votes. (a) Streamflow supply; (b) Groundwater supply; (c) Mixed streamflow and groundwater supply. 
Obviously, the renewal of drip irrigation networks was placed far ahead of other measures in drip irrigation areas (Figure 8c,d), and channel renewal was the most voted for measure in gravity irrigation areas; however, in areas that predominantly used gravity irrigation (50-75\%), drip irrigation renewal was in higher demand than channel renewal. The highest support for drip irrigation network renewal (92\%) was recorded in groundwater areas (Figure 9), where votes for this measure tripled those received for the second most voted measure.

\section{Discussion}

\subsection{More Subsidized Water Saving Infrastructures?}

After three decades of strong public investment in the modernization of irrigation systems, the regional irrigation sector faces new challenges, emanating both from a new economic and environmental context—associated with climate change and the globalization of agricultural markets-as well as from the irrigation modernization process itself. In this sense, it is particularly interesting to observe how, during the workshops, the measure in highest demand was investment in new infrastructure works to renovate the irrigation facilities, which have already become obsolete or will deteriorate in very few years. This measure was mainly voted for in groundwater areas $(92 \%)$, probably because these zones were the first to install these systems [39].

This fact highlights the limited durability of the pressurized irrigation technologies installed in recent decades. In some cases, the materials themselves have caused the system's deterioration, but in others, the necessity to replace or renovate infrastructure is a consequence of the early introduction of immature technology to inexperienced farmers and irrigation communities, through a process stimulated by industrial providers and easily accessible subsidies [13]. At the same time, infrastructure obsolescence and deterioration reveal the dependence on future investment needs that was not taken into account when the modernization of these irrigation systems took place. Due to the significant involvement of the regional and national governments in financing the modernization process, this dependence also affects the political commitment of the state, which will be pressed to maintain a high level of economic support for investment in the renewal of irrigation infrastructure. In fact, the participating farmers also expressed during the workshops, both in the voting and in the subsequent conversations, the need for both the regional and national governments to continue subsidizing investment in irrigation.

According to the results of the workshops, the expansion of drip irrigation has not yet finished, and irrigation communities still expect to introduce this technique-with the support of the regional or national governments-in another 42,000 ha, which would set the ceiling for this irrigation technique at $242,000 \mathrm{ha}$, or $81 \%$ of the current irrigated land. In the future, it may only be absent from two types of landscape: first, the small traditional irrigation systems in mountain areas, where pressurized irrigation only appears in a few isolated projects involving the transformation of formerly rain-fed areas; and second, two large historical huertas (market gardens) of outstanding heritage and cultural value, the Vega Baja del Segura and the Horta de València (Figure 1, clusters 3 and 13), where users-and elements of society-prefer to opt for other forms of modernization that are more respectful of this legacy. In the first of these two workshop-areas, farmers argued that "the term modernization has been perverted", by reducing it only to drip irrigation and marginalizing other alternatives to improve irrigation efficiency in traditional networks. Farmers in the protected area of the Horta de València (declared a Globally Important Agricultural Heritage System by the FAO and host to a Ramsar site) shared these opinions and called for the recognition of the environmental and cultural services of traditional irrigation, demanding the creation of some sort of economic compensation for these services.

The modernization program launched by the national and regional governments in the mid-1990s had two main objectives: to increase irrigation efficiency to bring about water saving, and to increase productivity. However, the importance of the first objective 
in the messages sent through the mass media eclipsed the second. In 1995, the Master Plan for the Modernization of Irrigation in the Valencia Region [40] had admitted a situation of growing deficit that in some districts presented "dramatic overtones". The solution should be undertaken "through a strategy of saving, reusing and improving the efficiency of water for irrigation", based on a generous programme of public subsidies, under the coordination of both the regional and national governments and the irrigation communities.

In contrast to assumptions underlying the regional and national irrigation policies, recent research [41-45] shows that subsidy policies are unlikely to provide real water conservation under some particular river basin conditions. In fact, the European Union has stated that funding to improve irrigation efficiency is limited to those ways that are consistent with the Water Framework Directive objectives and prevent the rebound effect [46]. However, according to the opinions expressed during the meetings, most farmers' representatives do not perceive this rebound effect, because they cannot properly assess the whole balance of the regional water cycle, and because drip expansion did not entail irrigation expansion or agricultural intensification in the majority of the irrigated areas in this region. On the contrary, they have observed a significant decrease in annual water volume use after introducing drip irrigation [47], and also substantial benefits in convenience and production, which lead them to enthusiastically support drip installation [48]. The fact that in this region drip irrigation expansion has not been accompanied by an increase in irrigated land, but by a decrease due to land abandonment, has reinforced this perception. In fact, during a few meetings, some drip users blamed gravity irrigation communities for "wasting" water, and in one case, a gravity irrigation community refused to attend the workshop to which it was invited, instead attending one in another district in order to avoid being rebuked by its neighbors for not adopting drip irrigation. This reveals the stigmatization of certain categories of farmers who are considered "reluctant" to change and resistant to the wider modernization process-something that has been observed in other world regions [49]. It is also significant that, while the lack of drip irrigation networks was ranked as the 38th problem during the assessment, the necessity to install drip irrigation systems was identified as the 9 th necessity.

\subsection{Water Security and Integrated Water Resource Management}

Unexpectedly, water resource availability was not seen as the primary concern in districts with the weakest water balances. Even in those districts with abundant water resources, concern for water security ranked higher. The explanation for this paradox is that in those areas lacking water resources, farmers' associations have identified the strategies and solutions to increase water resource availability and quality, and have clearly formulated and prioritized these proposals, both in the assessment and in the design of measures. This displaced water security to a less significant position. Water security is a broad concept that is interpreted in different ways in agricultural systems-not only from a conceptual perspective $[50,51]$ but also in the way users perceive it in different geographical contexts.

The solutions that farmers have devised to improve their guarantee of supply are varied and depend on geographic attributes. In many cases, these are relatively simple infrastructures such as new pipelines or small regulation reservoirs, aimed at achieving better conjunctive use schemes by integrating the management of groundwater and surface resources. However, the incorporation of wastewater and desalinated water for irrigation is much more complex and presents significant water quality, topographic and legal constraints, with effects on the economic cost. First, desalination plants and most treated wastewater plants are located in the urbanized coastal areas. This makes it necessary to build pumping stations and pipelines to bring these nonconventional resources to agricultural users, in most cases overcoming great distances and topographical irregularities. The Spanish legal framework for water also forces them to bear all the pumping costs necessary to reuse the water, regardless of the elevation at which urban users take the resource from nature (sometimes higher) and the higher economic capacity of urban users to absorb said 
costs. Secondly, to free up the use of these purified resources it is also necessary to incorporate desalination treatments, since the problem generated by the processes of marine intrusion into the coastal sewage systems is often compounded by the intrinsic salinity of urban wastewater. Third, the current Spanish legal framework transfers to agricultural users the responsibilities (on the impact on consumers) derived from the use of water of insufficient quality, which generates considerable legal uncertainties among farmers.

In short, the urban users in several districts do not return water resources in the condition (quality) and to the place (altitude) where they took it from nature, this cost being transferred to other potential users (agriculture), which is not in the spirit of the Spanish Water Law or the EU Water Framework Directive. Farmers highlighted these facts during the meetings and, in order to cope with these limitations, proposed different local solutions, practically all of which were based on the premise of full financing by the state.

The legal framework makes it difficult to integrate unconventional resources into management systems. This fact is a corollary of the sectoral planning of large infrastructures, through plans that facilitated investment, but did not overcome legal obstacles or correctly identify potential users. Unlike what happened in Israel [52,53], where a good fit has been achieved between the use of desalinated water (mainly reserved for urban use) and treated wastewater (for agricultural use), in Spain the construction of desalination plants followed a biased political approach [54,55], and was largely oriented towards an agricultural sector that lacked the economic capacity to bear the desalination costs. Without a national strategy involving legal reforms to integrate nonconventional resources, establishing a fairer and more realistic distribution of economic and environmental burdens between agricultural and urban users, regional governments could end up financing expensive local solutions to overcome the existing legal difficulties.

\subsection{The Water-Energy Nexus}

The enormous investment effort in modernizing irrigation systems has generated a significant increase in the agricultural energy consumption of the region, as the massive adoption of pressurized systems requires an energy use that was unnecessary in traditional gravity systems. If, prior to 1990, energy expenditure was basically limited to areas supplied with groundwater, the massive pressurization of the irrigation networks has generated a notable increase in irrigation tariffs in areas supplied by surface water, and a moderate rise or stabilization in areas that use groundwater [47], as has also happened in other regions [20,56-58]. This issue was underestimated during the process of public promotion of drip irrigation and worsened after the changes introduced by the state to the agricultural electricity tariffs in 2008 and 2013. In the latter change, popularly known as the "tarifazo" (rate hike), energy tariffs increased by $80 \%$ [59].

Consequently, during the workshops, energy costs have been identified as one of the main problems in the sector, particularly in those areas supplied by groundwater, and also in all those where drip irrigation predominates. They have also been prominent in citrus monoculture areas, where the increase in irrigation costs and other inputs has coincided with the stagnation of orange prices. These areas are, consequently, those where irrigators expressed a greater interest in the introduction of renewable energies during the workshops. They have observed positive experiences in the region [60], with local pioneer WUAs installing photovoltaic systems being able to recover the investment costs in 10 years and reduce energy costs to near zero.

The recent development of renewable energies emerges as an essential opportunity to reverse the growing trend in energy costs. In the case of photovoltaic energy, various factors combine that make this technology a priority. Installation costs have fallen, and the recent elimination of what was commonly known as the "sun tax" (RD-Law 15/2018) has notably improved its competitive capacity. Furthermore, the introduction of photovoltaic systems is aligned with the European Union's energy strategy, reflected in several documents such as the Commission's Green Paper (8 March 2006) to provoke a new industrial revolution and create a high-efficiency economy, energy, and low $\mathrm{CO}_{2}$ emissions; or the "Clean Energy 
Package for all Europeans" committed to reducing $\mathrm{CO}_{2}$ emissions by at least $40 \%$ by 2030 . This public commitment is perceived by farmers as an opportunity to obtain financial support from the regional and national governments to introduce photovoltaic energy, and consequently reduce energy costs. Climate change policies and agricultural economic interests are converging.

The installation of photovoltaic power stations in some districts is faced with a lack of available land, a fact that led some farmers to suggest investigating the use of other renewable energies, or for other alternatives to have been proposed locally. This is the case of the citrus growing area of the Millars River (20,000 ha), where some irrigators have requested public financial support to move the historical intake point $15 \mathrm{~km}$ upstream, in order to achieve a sufficient altitude to be able to pressurize their drip irrigation networks through gravity. This is potentially an interesting solution for farmers, but the impact on the ecological flow on river reach should be assessed in this type of initiative.

\subsection{Beyond the Infrastructure}

In addition to the notable increase in energy consumption, the massive adoption of drip irrigation sponsored by the public sector has generated other problems in the region. One of those most frequently identified, as other authors have already highlighted [48,61], is the theft of metallic materials from new infrastructures (rated as the third problem in predominantly drip areas), which adds unforeseen costs to the O\&M tasks. However, aside from the infrastructure, during the workshops, farmers' representatives criticized the infrastructural bias of the modernization mission. They denounced the lack of training support and advice that would allow them to make more efficient use of new technologies and that would also facilitate the resolution of administrative and bureaucratic problems. This training was demanded for farmers in general, and specifically for technicians hired by the irrigation communities. These training activities were the fifth most demanded measure in the region, and were mainly supported in those areas where drip irrigation had become clearly predominant.

This was not the only social or institutional measure requested by farmers. Many workshops revealed the need to create communities of users at the district level (general communities or central boards according to the Spanish legislative framework) that would integrate different irrigation communities, in order to achieve better management of the resource and reduce management costs. Previous studies have already noted [47] that the process of transformation to drip irrigation has resulted, in many territories, in a lost opportunity to promote merging processes of small irrigation entities. In several of the meetings, the users were in favor of starting these processes, but in two different workshops they stressed that the existence of a common infrastructure to share is a key catalyst for these processes (or a common access to water resources), since this forces the launch of collective management action, beyond the mere coordination of the shared use of an aquifer or a river section with individual access points. This is consistent with the idea that having well-defined boundaries of the resource-system is one of the main drivers for sustainable collective action [62-64].

\section{Conclusions: The Post-Modernization Era}

Most of the irrigation modernization policies have focused on the provision of infrastructures and new technologies to improve the efficiency of the conveyance and application of irrigation water. These policies have been predominant in most arid and semi-arid countries [7,30,31,42,65-67], and in many cases there has been no regional-scale reflection on their effects, nor a participatory exploration on what direction future policies should take. This study has sought to cover part of this deficit by trying to identify, over a very broad sample set, how irrigators value where these policies have led them and where they want to go-in other words, how they cope with the post-modernization era for irrigation, a new stage after a prolonged period of technical changes and investment efforts, 
which has led irrigators in Spain —and probably in many of the world's arid and semi-arid regions - to face both new challenges and old problems.

For nearly three decades, the WUAs of the autonomous region of Valencia have followed a subsidized irrigation modernization programme, whose main official objectives, according to its legal formulation, were to improve irrigation efficiency in order to save water, and to increase agricultural productivity. Unfortunately, after 30 years, and because of multiple factors, the original policy goals are far from being achieved, as this research demonstrates. The assessment made by the water users highlighted farmers' concern for both the lack of water resources and the processes of land abandonment due to the lack of profitability of agriculture. Despite this, farmers continue to demand investments in drip irrigation to improve their convenience and productivity and, as our results show, perceive less risk of land abandonment in those areas already using pressurized irrigation. They highlight the need for other farmers to use these techniques to reduce water demand, although scientific literature has questioned this effect $[68,69]$. There is a clear discrepancy between farmers' perceptions and academic research, which leaves policymakers of numerous world regions in a difficult situation.

Modernization policies have brought about, among many other changes, two new problems in the region: they have generated a strong need for investment for the renovation of drip irrigation infrastructures and have increased the vulnerability of farmers to the increase in the energy tariff. For irrigation, the post-modernization era reveals a context in which old weaknesses persist and new problems caused by thirty years of modernization emerge. Consequently, farmers resort to both well-known formulae and some innovative measures. Along with supporting investments to renovate or expand water-saving infrastructures, irrigators demand an improvement in knowledge, through training and advisory actions, as well as various legal and institutional changes. In addition, they aspire to change the irrigation energy model, mainly through the incorporation of photovoltaic energy, in line with the decarbonization suggestions made by international authorities to mitigate climate change. Although climate change is a clear objective of the national policies, farmers are not motivated by this global crisis, but by reducing irrigation costs. The interests of the public sector and users are different, but they converge in the same solution, the use of solar energy.

Between the initial assessment and the proposal of measures, several problems were side-lined or only partially answered. Land abandonment is the clearest example of this. Farmers found no way to overcome this situation, which demands a more complex and detailed analysis and measures that go beyond the regional policies and the modernization strategies. Meanwhile, WUAs are trapped on a hamster wheel, demanding and planning infrastructure investments while being strongly dependent on the injection of public investment to sustain their endurance, in order to cope with the challenges of climate change and an unfavorable market.

Author Contributions: Conceptualization, Á.R., J.M.-J., C.S.-I., M.O.-R., A.G.-G.; methodology, Á.R., J.M.-J., C.S.-I., M.O.-R., A.G.-G.; investigation, C.S.-I., M.O.-R., A.G.-G., J.M.C., J.M.-J., M.G.-M., Á.R.; writing—original draft preparation, C.S.-I.; writing—review and editing, M.O.-R., A.G.-G., J.M.C., J.M.-J., M.G.-M., Á.R.; project administration, Á.R.; funding acquisition, Á.R., J.M.-J., C.S.-I. All authors have read and agreed to the published version of the manuscript.

Funding: This work has been developed under the framework of the research agreement "Estudio para la modernización del regadío en la Comunidad Valenciana", between the Universitat Politècnica de València and the Generalitat Valenciana, and conducted as part of the research project "Design and evaluation of strategies to adapt to global climate change in Mediterranean watersheds by using irrigation water intensively (ADAPTAMED)" (RTI2018-101483-B-I00), funded by the Ministerio de Economía y Competitividad (MINECO) of Spain and with EU FEDER funds.

Institutional Review Board Statement: Not applicable.

Informed Consent Statement: Not applicable. 
Data Availability Statement: The data presented in this study are available on request from the corresponding author.

Acknowledgments: The authors would like to thank Iban Balbastre and Virginia Palau for their help in two workshops, and to highlight the excellent work done by a team of internship students during the meetings campaign. Muchas gracias Carmen Ferreras López, Enrique Peiró Soriano, Zulema Rodríguez Hernández, Rocío Giménez Haro, Andrea Martínez Oliver y Andrea Berruga Pérez.

Conflicts of Interest: The authors declare no conflict of interest.

\section{References}

1. Siebert, S.; Kummu, M.; Porkka, M.; Döll, P.; Ramankutty, N.; Scanlon, B.R. A global data set of the extent of irrigated land from 1900 to 2005. Hydrol. Earth Syst. Sci. 2015, 19, 1521-1545. [CrossRef]

2. FAO. Modernization of Irrigation Schemes: Past Experiences and Future Options Bangkok, Food and Agriculture Organization. In Proceedings of the Expert Consultation, Bangkok, Thailand, 26-29 November 1996. Available online: http:/ / www.fao.org/3/ X6959E/X6959E00.htm (accessed on 23 March 2021).

3. FAO. Modernization of Irrigation System Operations. In Proceedings of the 5th ITIS Network International Meeting, Food and Agriculture Organization, Aurangabad, India, 28-30 October 1998. Available online: http://www.fao.org/3/X6626E/x6626e00. htm (accessed on 23 February 2021).

4. World Bank. Projects in Irrigation and Drainage. 2021. Available online: https://projects.worldbank.org/en/projects-operations / projects-list?sectorcode_exact=AI (accessed on 25 February 2021).

5. International Commission on Irrigation and Drainage (ICID), World Irrigated Area 2018. Available online: https://www.icid. org/world-irrigated-area.pdf (accessed on 23 February 2021).

6. Molle, F.; Sanchis-Ibor, C. Irrigation Policies in the Mediterranean: Trends and Challenges; Molle, F., Sanchis-Ibor, C., Avella, L., Eds.; Springer: Berlin/Heidelberg, Germany, 2019; pp. 279-314.

7. Khadra, R.; Sagardoy, J.A. Irrigation Governance Challenges in the Mediterranean Region: Learning from Experiences and Promoting Sustainable Performance; Springer: New York, NY, USA, 2019.

8. Molle, F.; Sanchis-Ibor, C. Introduction; Molle, F., Sanchis-Ibor, C., Avella, L., Eds.; Springer: Berlin/Heidelberg, Germany, 2019; pp. 1-14.

9. Benouniche, M.; Zwarteveen, M.; Kuper, M. Bricolage as innovation: Opening the black box of drip irrigation systems. Irrig. Drain. 2014, 63, 651-658. [CrossRef]

10. Van der Kooij, S.; Zwarteveen, M.; Kuper, M. The material of the social: The mutual shaping of institutions by irrigation technology and society in Sequia Krichfa, Morocco. Int. J. Commons 2015, 9, 129-150. [CrossRef]

11. Ortega-Reig, M.; Sanchis-Ibor, C.; Palau-Salvador, G.; García-Mollá, M.; Avellà-Reus, L. Institutional and management implications of drip irrigation introduction in collective irrigation systems in Spain. Agric. Water Manag. 2017, 187, 164-172. [CrossRef]

12. García-Mollá, M.; Ortega-Reig, M.; Boelens, R.; Sanchis-Ibor, C. Hybridizing the commons: Privatizing and outsourcing collective irrigation management after technological change in Spain. World Dev. 2020, 132, 104983. [CrossRef]

13. Poblador, N.; Sanchis-Ibor, C.; Kuper, M. The Landing of Parachuted Technology: Appropriation of Centralised Drip Irrigation Systems by Irrigation Communities in the Region of Valencia (Spain). Water Altern. 2021, 14, 88-107.

14. Lecina, S.; Isidoro, D.; Playán, E. and Aragüés, R. Irrigation Modernisation in Spain: Effects on Water Quantity and Quality-A Conceptual Approach. Int. J. Water Resour. Dev. 2010, 26, 265-282. [CrossRef]

15. Berbel, J.; Mateos, L. Does investment in irrigation technology necessarily generate rebound effects? A simulation analysis based on an agro-economic model. Agric. Syst. 2014, 128, 25-34. [CrossRef]

16. Berbel, J.; Gutiérrez-Martín, C.; Rodríguez-Díaz, J.A.; Camacho, E.; Montesinos, P. Literature Review on Rebound Effect of Water Saving Measures and Analysis of a Spanish Case Study. Water Resour. Manag. 2015, 293, 663-678. [CrossRef]

17. Berbel, J.; Gutierrez-Marín, C.; Expósito, A. Impacts of irrigation efficiency improvement on water use, water consumption and response to water price at field level. Agric. Water Manag. 2018, 203, 423-429. [CrossRef]

18. Molle, F.; Tanouti, O. Squaring the circle: Impacts of irrigation intensification on water resources in Morocco. Agric. Water Manag. 2017, 192, 170-179. [CrossRef]

19. Pérez-Blanco, C.D.; Hrast-Essenfelder, A.; Perry, C. Irrigation Technology and Water Conservation: A Review of the Theory and Evidence. Rev. Environ. Econ. Policy 2020, 14, 216-239. [CrossRef]

20. Rodríguez-Díaz, J.A.; Pérez-Urrestarazu, L.; Camacho-Poyato, E.; Montesinos, P. The paradox of irrigation scheme modernization: More efficient water use linked to higher energy demand. Span. J. Agric. Res. 2011, 9, 1000-1008. [CrossRef]

21. Rocamora, C.; Vera, J.; Abadía, R. Strategy for Efficient Energy Management to solve energy problems in modernized irrigation: Analysis of the Spanish case. Irrig. Sci. 2013, 31, 1139-1158. [CrossRef]

22. Espinosa-Tasón, J.; Berbel, J.; Gutiérrez-Martín, C. Energized water: Evolution of water-energy nexus in the Spanish irrigated agriculture, 1950-2017. Agric. Water Manag. 2020, 233, 106073. [CrossRef]

23. López-Gunn, E.; Zorrilla, P.; Prieto, F.; Llamas, R. Lost in translation? Water efficiency in Spanish agriculture. Agric. Water Manag. 2012, 108, 83-95. [CrossRef] 
24. Garb, Y.; Friedlander, L. From transfer to translation: Using systemic understandings of technology to understand drip irrigation uptake. Agric. Syst. 2014, 128, 13-24. [CrossRef]

25. Venot, J.P.; Zwarteveen, M.; Kuper, M.; Boesveld, H.; Bossenbroek, L.; van der Kooij, S.; Wanvoeke, J.; Benouniche, M.; Errahj, E.; de Fraiture, C.; et al. Beyond the promises of technology: A review of the discourses and actors who make drip irrigation. Irrig. Drain. 2014, 63, 186-194. [CrossRef]

26. Soto-García, M.; Martínez-Álvarez, V.; García-Bastida, P.; Alcón, F.; Martin-Gorriz, B. Effect of water scarcity and modernisation on the performance of irrigation districts in south-eastern Spain. Agric. Water Manag. 2013, 124, 11-19. [CrossRef]

27. Playán, E.; Salvador, R.; López, C.; Lecina, S.; Dechmi, F.; Zapata, N. Solid-Set Sprinkler Irrigation Controllers Driven by Simulation Models: Opportunities and Bottlenecks. J. Irrig. Drain. Eng. 2014, 140, 1-10. [CrossRef]

28. Tarjuelo, J.M.; Rodríguez-Díaz, J.A.; Abadía, R.; Camacho, E.; Rocamora, C.; Moreno, M.A. Efficient water and energy use in irrigation modernisation: Lessons from Spanish case studies. Agric. Water Manag. 2015, 162, 67-77. [CrossRef]

29. Cornwall, A.; Jewkes, R. What is participatory research? Soc. Sci. Med. 1995, 41, 1667-1676. [CrossRef]

30. García-Mollá, M.; Sanchis-Ibor, C.; Avellà, L.; Albiac, J.; Isidoro, D.; Lecina, S. Spain; Molle, F., Sanchis-Ibor, C., Avella, L., Eds.; Springer: New York, NY, USA, 2019; pp. 89-121.

31. Venot, J.P.; Kuper, M.; Zwarteveen, M. (Eds.) Drip Irrigation for Agriculture: Untold Stories of Efficiency, Innovation and Development; Routledge: Abingdon, UK, 2017; pp. 96-98.

32. GVA. Informe Del Sector Agrari Valencià 2019: València: Generalitat Valenciana 2021. Available online: http:/ / www.agroambient. gva.es/va/informes-del-sector-agrario-valenciano (accessed on 31 January 2021).

33. INE. Encuesta de Superficies y Rendimientos de Cultivos de España; Instituto Nacional de Estadística: Madrid, Spain, 2020. Available online: https:/ / www.mapa.gob.es/es/estadistica/temas/estadisticas-agrarias/agricultura/esyrce/v (accessed on 1 July 2020).

34. INE. Censo Agrario 2009; Instituto Nacional de Estadística (Statistics National Institute): Madrid, Spain, 2011. Available online: http:/ / www.pegv.gva.es/es/temas/agriculturaganaderiaselviculturacazapescayacuicultura/censoagrario/censoagrario2009 (accessed on 1 July 2020).

35. Gallego-Bono, J.R. La agricultura a tiempo parcial y la externalización de servicios agrarios como vehículo del cambio estructural. REEAP 2010, 225, 13-45.

36. MAPA. Caracterización Del Sector Agrario en El Estado Español. Ministerio de Agricultura, Pesca y Alimentación; Ministry of Agriculture, Fisheries and Food: London, UK, 2019. Available online: https:/ /www.uaga.eus/el-mapa-publica-un-estudiosobre-la-caracterizacion-del-sector-agrario-en-el-estado/ (accessed on 1 July 2020).

37. Confederación Hidrográfica Del Júcar (CHJ). Plan Hidrológico de la Cuenca Del Júcar 2015-2021. Available online: https:/ /www. chj.es/es-es/medioambiente/planificacionhidrologica/Paginas/PHC-2015--2021-Plan-Hidrologico-cuenca.aspx (accessed on 23 February 2021).

38. Confederación Hidrográfica Del Segura (CHS). Plan Hidrológico de la Demarcación Del Segura 2015-2021. Available online: https: / / www.chsegura.es/es/cuenca/planificacion/planificacion-2015--2021/plan-hidrologico-2015--2021/index.html (accessed on 23 February 2021).

39. García-Mollá, M.; Sanchis-lbor, C.; Avellá-Reus, L. La modernización del regadío en las entidades de riego valencianas: Efectos en el uso y costes del agua. In Efectos de la Modernización de Regadios en España; Berbel, J., Gutiérrez Martín, C., Eds.; Cajamar: Almería, Spain, 2017; pp. 377-398.

40. DOGV. Master Plan for the Modernization of Irrigation in the Valencia Region, DECRETO 13/1995 de 10 de Enero, Del Gobierno Valenciano, Por El Que Se Aprueba El Plan Director de Modernización Del Regadío de la Comunidad. Available online: http:/ / www.dogv.gva.es/portal/ficha_disposicion_pc.jsp?sig=0185/1995\&L=1 (accessed on 25 February 2021).

41. Sur, M.; Umali-Deininger, D.; Dinar, A. Water Related Subsidies in Agriculture: Environmental and Equity Consequences. In Proceedings of the OECD Workshop on Environmentally Harmful Subsidies, Paris, France, 7-8 November 2002.

42. Scheierling, S.M.; Young, R.A.; Cardon, G.E. Public subsidies for water-conserving irrigation investments: Hydrologic, agronomic, and economic assessment. Water Resour. Res. 2006, 42. [CrossRef]

43. Ward, F.A.; Pulido-Velazquez, M. Water conservation in irrigation can increase water use. Proc. Natl. Acad. Sci. USA 2008, 105, 18215-18220. [CrossRef]

44. Pfeiffer, L.; Lin, C. Does efficient irrigation technology lead to reduced groundwater extraction? Empirical evidence. J. Environ. Econ. Manag. 2014, 67, 189-208. [CrossRef]

45. Dagnino, M.; Ward, F.A. Economics of Agricultural Water Conservation: Empirical Analysis and Policy Implications. Int. J. Water Resour. Dev. 2012, 28, 577-600. [CrossRef]

46. European Commission. A Blueprint to Safeguard Europe's Water Resources, Communication from the Commission to the European Parliament, the Council, the European Economic and Social Committee and the Committee of the Regions 2012. Available online: https:/ / eur-lex.europa.eu/legal-content/EN/TXT/PDF/?uri=CELEX:52012DC0673\&from=EN (accessed on 15 March 2021).

47. Sanchis-Ibor, C.; García-Mollá, M.; Avellà, L. Effects of drip irrigation promotion policies on water use and irrigation costs in Valencia Spain. Water Policy 2017, 19, 165-180. [CrossRef]

48. Ortega-Reig, M.; Sanchis-Ibor, C.; García-Mollá, M. Drip irrigation in Eastern Spain: Diverging goals in a converging process. In Drip Irrigation for Agriculture: Untold Stories of Efficiency, Innovation and Development; Venot, J.P., Kuper, M., Zwarteveen, M., Eds.; Routledge: Abingdon, UK, 2017; pp. 96-98. 
49. Henriquez, D.; Kuper, M.; Escobar, M.; Chia, E.; Vasquez, C. Creating small farm entrepreneurs or doing away with peasants? State-driven implementation of drip irrigation in Chile. In Drip Irrigation for Agriculture: Untold Stories of Efficiency, Innovation and Development; Venot, J.P., Kuper, M., Zwarteveen, M., Eds.; Routledge: Abingdon, UK, 2017; pp. 122-133.

50. Liu, B.C.; Mei, X.R.; Li, Y.Z.; Yang, Y.L. The Connotation and Extension of Agricultural Water Resources Security. Agric. Sci. China 2007, 6, 11-16. [CrossRef]

51. Malekian, A.; Hayati, D.; Aarts, N. Conceptualizations of water security in the agricultural sector: Perceptions, practices, and paradigms. J. Hydrol. 2017, 544, 224-232. [CrossRef]

52. Feitelson, E. The four eras of Israeli water policies. In Water Policy in Israel: Context, Issues and Options; Becker, N., Ed.; Springer: Berlin/Heidelberg, Germany, 2013; pp. 15-32.

53. Lavee, D.; Feitelson, E.; Joseph-Ezra, H. Israel. In Irrigation in the Mediterranean: Technologies Institutions and Policies; Molle, F., Sanchis-Ibor, C., Avella, L., Eds.; Springer: Cham, Switzerland, 2019; pp. 213-241.

54. Swingedouw, E. Into the Sea: Desalination as Hydro-Social Fix in Spain. Water Supply Manag. 2013, 103, 261-270. [CrossRef]

55. Swingedouw, E.; Williams, J. From Spain's hydro-deadlock to the desalination fix. Water Int. 2016, 41, 54-73. [CrossRef]

56. Hardy, L.; Garrido, A. Análisis y Evaluación de Las Relaciones Entre El Agua y la Energía, Papeles de Agua Virtual 6, Madrid: Fundación Botín. Available online: https:/ / www.fundacionbotin.org/89dguuytdfr276ed_uploads/Observatorio\%20Tendencias / PUBLICACIONES/MONOGRAFIAS/PAV/PAV6.pdf (accessed on 25 January 2021).

57. Hardy, L.; Garrido, A.; Juana, L. Evaluation of Spain's Water-Energy Nexus. Int. J. Water Resour. Dev. 2012, 28, 151-170. [CrossRef]

58. Mayor, B.; López-Gunn, E.; Villarroya, F.; Montero, E. Application of a water-energy-food nexus framework for the Duero river basin in Spain. Water Int. 2015, 40, 791-808. [CrossRef]

59. De Durango, A.G. La Subida de Las Tarifas Eléctricas Ahoga a Los Regantes Españoles Iagua. Available online: https: / /www.iagua.es/noticias / tarifas /14/02/11/la-factura-electrica-de-los-regantes-se-ha-incrementado-en-mas-deun-80-desde-2008-45084 (accessed on 23 February 2021).

60. Todde, G.; Murgia, L.; Carrelo, I.; Hogan, R.; Pazzona, A.; Ledda, L.; Narvarte, L. Embodied Energy and Environmental Impact of Large-Power Stand-Alone Photovoltaic Irrigation Systems. Energies 2018, 11, 2110. [CrossRef]

61. González-Pavón, C.; Arviza-Valverde, J.; Balbastre-Peralta, I.; Carot Sierra, J.M.; Palau-Salvador, G. Are Water User Associations Prepared for a Second-Generation Modernization? The Case of the Valencian Community (Spain). Water 2020, 12, 2136. [CrossRef]

62. Agrawal, A. Common Property Institutions and Sustainable Governance of Resources. World Dev. 2001, 29, 1649-1672. [CrossRef]

63. Wade, R. Village Republics: Economic Conditions for Collective Action in South India; Institute for Contemporary Studies: San Francisco, CA, USA, 1994.

64. Ostrom, E. Crafting Institutions for Self-Governing Irrigation Systems, San Francisco; Institute for Contemporary Studies: San Francisco, CA, USA, 1992.

65. Molle, F.; Tanouti, O.; Faysse, N. Morocco. In Irrigation in the Mediterranean: Technologies Institutions and Policies; Molle, F., Sanchis-Ibor, C., Avella, L., Eds.; Springer: Cham, Switzerland, 2019.

66. Topçu, S.; Kibaroglu, A.; Kadirbeyoglu, Z. Turkey. In Irrigation in the Mediterranean: Technologies Institutions and Policies; Molle, F., Sanchis-Ibor, C., Avella, L., Eds.; Springer: Cham, Switzerland, 2019.

67. Wheeler, S.A.; Carmody, E.; Grafton, R.Q.; Kingsford, R.T.; Zuo, A. The rebound effect on water extraction from subsidising irrigation infrastructure in Australia. Resour. Conserv. Recycl. 2020, 159, 104755. [CrossRef]

68. Grafton, R.Q.; Williams, J.; Perry, C.J.; Molle, F.; Ringler, C.; Steduto, P.; Udall, B.; Wheeler, S.A.; Wang, Y.; Garrick, D. The paradox of irrigation efficiency. Science 2018, 361, 748-750. [CrossRef] [PubMed]

69. Perry, C.; Steduto, P. Does Improved Irrigation Technology Save Water? A Review of the Evidence; Food and Agriculture Organization of the United Nations: Cairo, Egypt, 2017. 